DOI: https://doi.org/10.47405/mjssh.v6i3.686

\begin{tabular}{|c|c|}
\hline 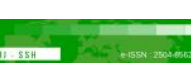 & Malaysian Journal of Social Sciences and Humanities (MJSSH) \\
\hline Malaysian Journal of & Volume 6, Issue 3, March 2021 \\
\hline (MJ-ssH) & e-ISSN : 2504-8562 \\
\hline & $\begin{array}{l}\text { Journal home page: } \\
\text { www.msocialsciences.com }\end{array}$ \\
\hline
\end{tabular}

\title{
Modeling the Commercial Property Value Using Ordinary Least Squared (OLS): A Case Study of Putatan, Sabah and Limbang, Sarawak
}

\author{
Oliver Valentine Eboy ${ }^{1}$, Avie Krista Anak Jurah ${ }^{1}$ \\ ${ }^{1}$ Geography Programme, Faculty of Social Sciences \& Humanities, Universiti Malaysia Sabah (UMS) \\ Correspondence: OliverValentine Eboy (oliver@ums.edu.my)
}

\begin{abstract}
Real Estate is an asset that provides profitable investment in return. Commercial property constitutes an important part of the real estate sector. In valuing commercial property, rental value is an essential component for valuers in applying valuation methods. Determining the rental value usually a difficult process as it involves a lot of influence factors. There are various factors that can be used but not the same for every commercial property. Therefore, this paper shows the modeling valuation comparison between two commercial property areas of Putatan and Limbang that represent the outskirts of the city in Sabah and Sarawak respectively. The purpose of this study is to find an effective approach to develop a suitable model for commercial property valuation using OLS and subsequently intends to identify factors that influence the commercial properties for both study areas. The OLS technique was used for this study to develop the property valuation model in Putatan and Limbang. The outcome shows that both study areas can be modeled using OLS for property valuation using similar factors but the Limbang area produced higher accuracy than Putatan based on the adjusted R2 value. However, in terms of the significant of the property value influence factors, both Limbang and Putatan produced different significant factors. Thus, it shows that most of the outskirt city commercial property valuation must be modeled using different influence factors. The model will benefit the local authorities, especially for commercial property valuation. Ultimately, revaluation also can be done easily with low cost, less time and few people needed for this approach.
\end{abstract}

Keywords: commercial property, rental value, property valuation, Ordinary Least Square (OLS)

\section{Introduction}

Real estate is consisting of land and buildings (Ismail Omar, 1997; Wyatt and Ralphs, 2003) that used for a variety of purposes such as residences, hotels, recreation, shopping centers, offices, banks and others (Lemias Ibin, 2007). Real estate is an object often used as a study and analysis material (Ring and Dasso, 1972) as it is a commodity that plays an important role in the global economy (Renigier-Biłozor et al., 2017). According to Lin (2010), the value of a property usually reflects the local economic growth. By knowing the property value, the place was able to be identified as developed or not (Oliver, 2015). The property values also have become the basis of property rating in which the local authorities used to impose tax on the property owners (Buang Alias, 2000; Oliver, 2015). Besides, property valuation is an important task for valuers to determine the said property value (Oliver, 2008). 
Millington (2001) defines property valuation as the art, or science, of estimating the value for a specific purpose of a particular interest in property at a particular moment in time, considering all the features of the property and also considering all the underlying economic factors of the market, including the range of alternative investments. Property valuation is also used to estimate property values for various uses such as sales, purchases, mortgages, rentals, insurance, estate taxes, stamp duty, and valuation of real estate taxes (Shapiro et al., 2009). Other than that, property valuation not only helps local authorities to calculate the right property tax to generate income in a developing area, but it also led investors to find suitable property areas for marketing, helping developers to track potential areas for the construction of real estate and propose refinancing or sale of real estate to the owner (Oliver, 2008).

Study regarding property valuation modeling on commercial property especially shop houses were never conducted in Limbang and Putatan area compared to other major cities in Sabah or Sarawak (Selamat Jati Yanjah, 2017; Christy Onyo, 2017; Watson Jeffrey Kaling, 2018). However, Limbang and Putatan were developing districts with various development activities being carried out such as housing development in selected areas construction of new industrial areas. Thus, this research is important to determine and assess to which extent the development has brought changes to the property sector in Putatan and Limbang.

Regression analysis is an analysis that is widely used in spatial statistics (Alexander and Schuster, 1998) and it can be used to model, examine, and explore spatial relationships, and that is to explain the factors behind the observed spatial patterns and predict the results (ESRI, 2017). Ordinary Least Square (OLS), which is one of the regression techniques, often used in estimating the rental value of the property based on location (Scott, 1988; Wyatt, 1997; So et al, 1997; Oliver and Ibrahim, 2007).

According to Oliver (2008), property valuation using spatial statistics within Geographic Information System (GIS) integration is very important as it is able to accelerate, facilitate and contribute to assessment activities. However, to measure or identifying the factors of influence towards the commercial property value, the property areas have to be segmented into separate models instead of an overall model (McCluskey et al., 2011). Therefore, this study was conducted to determine whether the two areas of Limbang and Putatan share the same factor of influence or must be modeled with different factors of influence.

\section{Literature Review}

\section{Location factor}

Location is a key factor in determining a property's value (Oliver and Ibrahim Sipan, 2008). A good location will influence the degree of visitors' accessibility to a business location (Netzell, 2013). Therefore, investors or businessmen are trying to find the best and will directly increase demand for the business lot. According to Gallimore et al. (1996), location will increase the value with multiple location influence. In other words, the influence of location is not seen in terms of the location of the business lot but rather the influence of the relative location of the business lot with the surrounding amenities such as the distance of business lot from the mall's main entrance and the distance from the amenity.

According to Wyatt and Ralphs (2003), location factor influencing commercial properties include access to markets, suplliers, open spaces, parking lots and train stations. Nevertheless, the influence of location factor on retail commercial real estate differs from business complex. This is due to the location factors affecting the business complex is more internal.

In identifying the factors that affect the rental value, there are several techniques that can be used such as Ordinary Least Squares (OLS). In this study, the OLS technique was used to see the influence of location factors in general in affecting the rental value. 


\section{Ordinary Least Squared (OLS)}

OLS is the most well-known analysis of all regression techniques (Scott and Janikas, 2010) as it has a function to predict a dependent variable from a set of independent variables (Tabachnick and Fidell, 1989). Shaw and Wheeler (1985) also argue that OLS is used to produce a relationship model between dependent variables with one or more independent variables, measuring error by using relationships to make predictions against dependent variables and measuring the relationship strength (correlation) between variables dependent and independent variables.

OLS is a global model that forms the single equation to represent the relationship between the object to be modeled with each variable description (Oliver and Edmund; 2010) It is quite easy to examine the model's assumptions such as linear, variance constant and the effect of outliers using a simple graphical method (Hutcheson and Sofronio, 1999). The formula can be stated as follows:

$$
\mathrm{V}=\mathrm{B}_{0}+\mathrm{B}_{1} \mathrm{X}_{1}+\mathrm{B}_{2} \mathrm{X}_{2} \ldots \ldots \mathrm{B}_{\mathrm{n}} \mathrm{X}_{\mathrm{n}}
$$

Where, $\mathrm{V}$ is the estimated rental value for each shophouse which is calculated as the sum of $\mathrm{B}_{0}$ (constant) and location influence variables $\left(\mathrm{B}_{1} \mathrm{X}_{1} \ldots \ldots \mathrm{B}_{\mathrm{n}} \mathrm{X}_{\mathrm{n}}\right)$.

With the integration of GIS, OLS now becomes part of spatial statistics that could be utilized to perform spatial regression in global environment. Such an approach potentially could help local authority to speed up revaluation process and reduce cost.

\section{Methodology}

In this study, for data collection, the non-random selection sampling techniques was used in this research. The questionnaires were distributed by the researchers to obtain data on the rent to owners of shops in the study area. Whereas, for the existing data such as maps of shophouse lots were obtained from Limbang Division Land and Survey Department, Putatan District Council and Property Services and Valuation Department. In this study, the data of 232 ground floor shop houses rental have been collected in the area of Limbang and 100 ground floor rental for Putatan area as shown in Figure 1 and figure 2.

Figure 1: Shophouse at Limbang commercial area

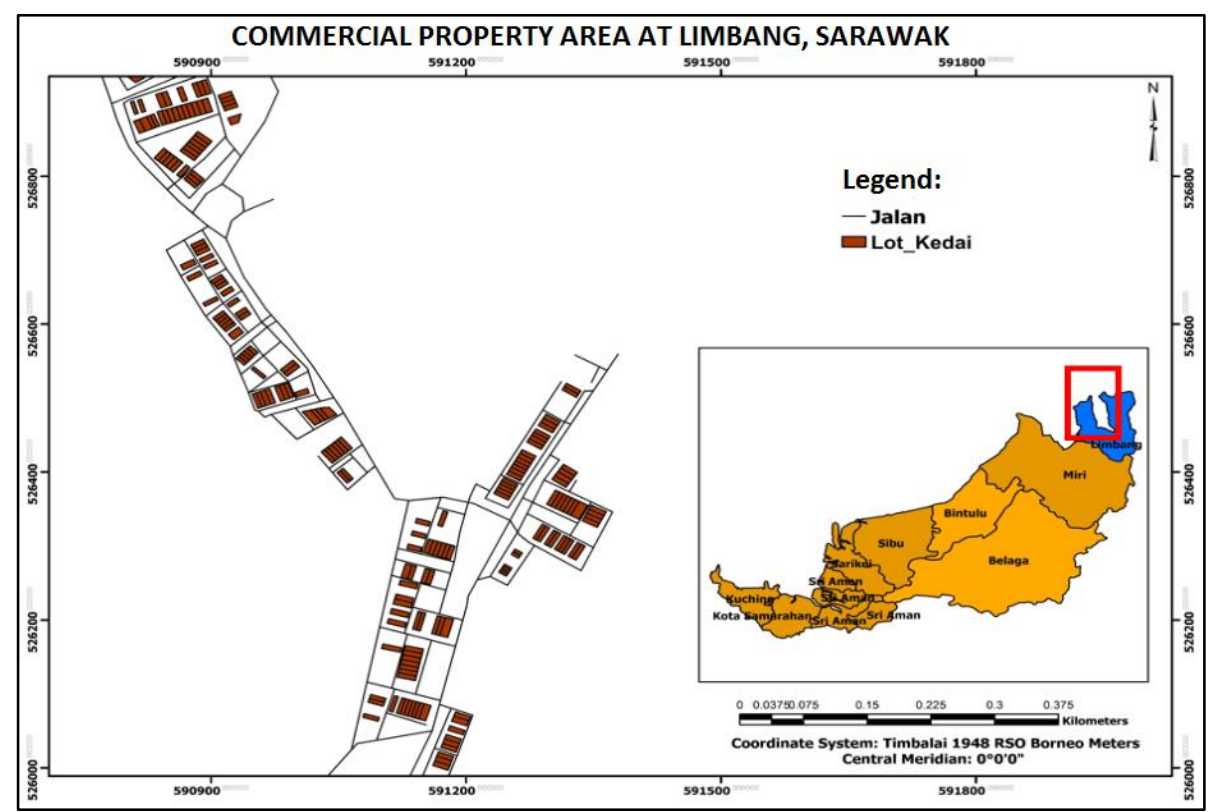

Source: Valuation and Property Services Department (2018): Land and Survey Department of Limbang, Sarawak (2018) (Modified) 
Meanwhile, 20 location factors such as renovation, main roads, secondary roads, educational centers, leisure centers, banks, police stations, post offices, bus stops or taxis, ferry terminals, public toilets, places of worship, petrol stations, parking lots, shopping complexes, office complexes, sports complexes, farmer's markets, convenience and position have been used for the OLS modeling purpose for both study areas.

Attribute data for the location factors in this research using the "Dummy" code or indicator variables (1 or 0$)$ that describes the effect of the location of the property. For example, the code " 1 " indicates that the property was influenced by the location factor, behind the code " 0 " describes the area that was not influenced by the location factor. Generally, the more the area influenced by the location factor, the higher the influence received. In addition, this research does not use measuring tools such as GIS buffer analysis or network analysis to measure the distance between the location factor and the area.

Figure 2: Shophouse at Putatan Commercial Area

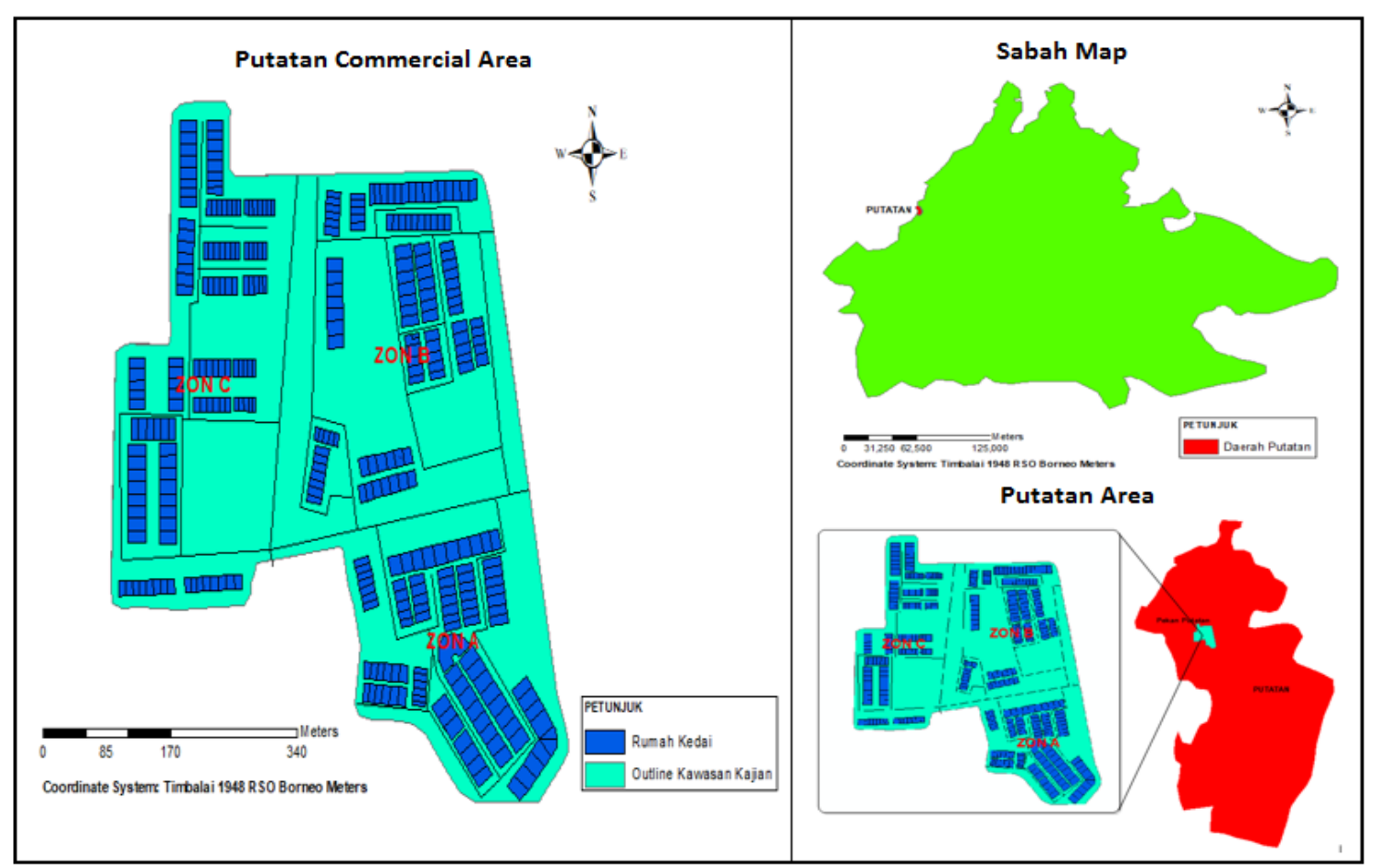

\section{Result}

Table1 shows the comparison of OLS analysis with the district of Limbang and Putatan. The estimation is been done using ArcGIS 10.3 software.

Table1: Comparison of OLS for Limbang and Putatan district

\begin{tabular}{lcc}
\hline & OLS LIMBANG & OLS PUTATAN \\
\hline Akaike's Information Criterion (AICc) & 2892.2944 & 5993.4010 \\
Adjusted R-Squared & 0.70 & 0.59 \\
\hline
\end{tabular}

Based on the results above, it can be said that the OLS model for Limbang is better than Putatan, in which the adjusted R2 of 0.70 for Limbang is higher than Putatan (0.59). Theoretically, the higher the R2 the better the model to predict the value of the property (Hishamuddin M. Ali, 1998). OLS model is also capable to identify the significant and the strength of the influence of the location factor to the shophouses' rental value (Oliver, 2006). 
To assess the goodness of fit and residual of the model, the comparison between different regression models were examined with the Akaike Information Criterion (AIC) measurement. Comparison between the spatial model would be examined with the model having the lowest AIC will be the better model provided that the differences in value are more than 3 (Fotheringham et al., 2002; ESRI, 2013). AIC for Limbang proves to be the better model as the value of 2892.2994 was smaller than Putatan with 5993.4010 .

Based on the OLS analysis, the OLS model for Limbang district shows that there are only 6 significant factors that influence the shophouse property value at 95\% accuracy level which consists of Market, Petrol Station, Public Toilet, Recreational Park, Position and Office. While the Putatan district only has 5 significant factors that comprise of renovation, road, main rubbish area, shopping complex, and Hotel.

To determine the strength and type of relationship the independent variable has to property value, the coefficient for each of the independent variable were measured. Table 2 and Table 3 show the coefficient value of each significant independent variable for the Limbang and Putatan area respectively. For Limbang in Table2, the shopping complex and the main rubbish area produced a strong positive relationship with a coefficient of 1792.353326 and 1596.874556 respectively. While ROAD and RENOVATION indicate a moderate positive relationship with a coefficient of 671.139292 and 772.585736 respectively. On the other hand, HOTEL shows a strong negative relationship with coefficient of -2257.757305 .

Table 2: Relationship type for the significant influence factors to the commercial property value of Limbang

\begin{tabular}{lll}
\hline $\begin{array}{l}\text { Commercial Property } \\
\text { Factor of Influence }\end{array}$ & Coefficient $(\mathbf{B})$ & Type of relationship with property value \\
\hline Renovation & 671.139292 & Moderate positive relationship \\
Road & 772.585736 & Moderate positive relationship \\
Main Rubbish Area & 1596.874556 & Strong positive relationship \\
Shopping Complex & $\mathbf{1 7 9 2 . 3 5 3 3 2 6}$ & Strong positive relationship \\
Hotel & $\mathbf{- 2 2 5 7 . 7 5 7 3 0 5}$ & Strong negative relationship \\
\hline
\end{tabular}

As for Putatan in Table 3, a coefficient of 1756.074847 associated with MARKET to the shophouses representing the RM currency can be interpreted as an increase of RM1756.074847 to the property value. This shows that MARKET gives a high positive increase to the shophouse's value in the study area. Another independent variable that provided a high positive increase to the shophouses value is the PETROL STATION with a coefficient value of 1613.136466. The other factors of PUBLIC TOILET and RECREATIONAL CENTRE also give a high positive increase coefficient value of 1277.620279 and 602.713272 respectively. While POSITION gives a high negative coefficient value of -1353.385523 to the shophouses value. This is followed by OFFICE CENTRE with coefficient value - 410.054356 .

Table 3: Relationship type for the significant influence factors to the commercial property value of Putatan

\begin{tabular}{lll}
\hline $\begin{array}{l}\text { Commercial Property Factor } \\
\text { of Influence }\end{array}$ & Coefficient (B) & $\begin{array}{l}\text { Type of relationship with property } \\
\text { value }\end{array}$ \\
\hline Market & 1756.074847 & Strong positive relationship \\
Petrol Station & 1613.136466 & Strong positive relationship \\
Public Toilet & 1277.620279 & Strong positive relationship \\
Recreational Centre & 602.713272 & $\begin{array}{l}\text { Moderate positive relationship } \\
\text { Position }\end{array}$ \\
\hline
\end{tabular}


DOI: https://doi.org/10.47405/mjssh.v6i3.686

\begin{tabular}{lll}
\hline Office Centre & -410.054356 & Moderate negative relationship \\
\hline
\end{tabular}

\section{Discussion}

Ultimately, based on the two models of OLS Limbang and OLS Putatan, it can be said that the significant influence factors for both models are different even though there are using a similar list of variables. This shows that each area need to be developed with different model to accurately estimate the property value of the area. The Limbang model, however, provides the highest accuracy and suitable to be used for the authorities compare with the Putatan model. This could be due to the factors involved in the model really reflect the commercial property value in the Limbang area (Christy Onyo, 2017). A different set of influence factor might be needed to obtain an accurate OLS model for Putatan.

\section{Conclusion}

Identifying a significant property valuation factor is a difficult task especially when conducting manual valuation. By using OLS modeling, this activity can be done easily. Other than that, OLS modeling can help determine the accuracy of the property value prediction. Although both study area of Limbang and Putatan are within the outskirt city, the modeling shows that the significant influence factors for the commercial property valuation are different. Therefore, different models must be developed for different commercial property areas to accommodate the significant influence factors that exist in the said area. Even though the OLS model can produce good property value prediction but this can only be done on a global scale. Another regression modeling through Geographical Weighted Regression (GWR), also capable of conducting property value estimation but on a local scale. This is suitable for non-stationarity property value in the area, which means there are high differences of value in certain areas that only GWR can detect. Therefore, GWR modeling would be another method that should be explored for further studies in Putatan and Limbang. Finally, this study will benefit the local authorities, the investors and the business people to identify the property value influence and the estimated value with low cost, less time and few people needed using this approach.

\section{References}

Land and Survey Department of Limbang, Sarawak. (2017). Shophouses Lot in Limbang Town. Alexander and Schuster. (1998). Regression Analysis for Social Sciences. Academic Press: USA.

Buang Alias. (2000). Analysis of factors that contribute to the accumulation of uncollected rates in local authorities in Malaysia. PhD, Universiti Teknologi Malaysia, Skudai, Johor.

Christy Onyo (2017). Personal COmmunication. Jabatan Tanah dan Ukur, Limbang. Pegawai Penilaian, Jabatan Tanah dan Ukur Bahagian Limbang, Sarawak.

Demaris, A.shophouses (2004). Regression With Social Data: Modelling Continuos and Limited Response Variables. John Wiley \& Sons, Inc.

ESRI. (2018). How Exploratory Regression Works. Online: http://pro.arcgis.com/en/pro-app/tool-reference/spatial-statistics/how-exploratory-regressionworks.html

ESRI. (2013). Geographically Weighted Regression (Spatial Statistics). Retrieved 1May 2013, from http://resources.esri.com/help/9.3/arcgisdesktop/com/gp_toolref/spatial_statistics_tools/geograp hically_weighted_regression_spatial_statistics_.htm

Fotheringham, A. S., Brunsdon, C., \& Charlton, M. (2002). Geographically weighted regression: The analysis of spatially varying relationships. New York, NY: John Wiley \& Sons.

Gallimore, P., Fletcher, M. and Carter, M. (1996), "Modelling the influence of location on value", Journal of Property Valuation and Investment, Vol. 14(1), 6-19.

Hishamuddin. M. Ali (1998). Pembentukan Model Penawaran Optimum bagi Harta Tanah Perdagangan di Taman Perumahan. Universiti Teknologi Malaysia. Laporan Akhir VOT 71932. 
Hutcheson, G. and Sofroniou, N. (1999). The Multivariate Social Scientist Introductory Using Generalized Linear Models. SAGE Publications Ltd.

Ismail Omar (1997). Penilaian Harta Tanah. Dewan Bahasa Dan Pustaka: Kuala Lumpur.

Lemias Ibin (2007). Aplikasi Sistem Maklumat Geografi (GIS) dalam Pembangunan Peta Nilai Harta Tanah Di Kota Kinabalu Tahun 1995 Hingga Tahun 2006.

Lin, C. C. (2010). Critical analysis and effectiveness of key parameters in residential property valuations. Unpublished $\mathrm{PhD}$, State University of New York, Buffalo, NY.

McCluskey, W. J., \& Borst, R. A. (2011). Detecting and validating residential housing submarkets: A geostatistical approach for use in mass appraisal. 4(3), pp. 290-318. DOI:10.1108/17538271111153040

Millington, A. F. (2001). An Introduction to Property Valuation (5th ed.): Estate Gazette, London.

Netzell, O. (2013). The effect of accessibility on retail rents: testing integration value as a measure of geographic location. Journal of Property Research, 30(1), 1-23.

Oliver V. Eboy (2008). The Role of GIS for Property Valuation Support. The New Era for Asia GIS: Asia GIS 2008 Joint Conference of KAGIS Fall Symposium. Busan, Korea. 26-27September 2008.

Oliver V. Eboy (2006). Determining the Influence of Location Shop House's Rental Value Using Spatial Statictics Techniques. Proceedings of The Interational Real Estate Research Symposium (IRERS) 11 - 13 April 2006, PWTC Kuala Lumpur, Malaysia.

Oliver V. Eboy and Edmund Sepikit (2010). Spatial Statistics Modelling in Property Valuation. ICT \& Geospatial Technology Conference For Local Authority 2010. Delivering Quality Services Through Innovation (Green \& Smart Tecnology. Geospatial Techonology. eValuation) 23-24 November 2010. Kota Kinabalu, Sabah.

Oliver V. Eboy and Ibrahim Sipan (2007). Modelling Interaction of Location Influence with Rental Value on Commercial Properties Using Spatial Statistic Techniques. Journal of Valuation and Property Services. Vol 7. No 1. 2007.

Renigier-Biłozor, M., Biłozor, A., Wiśniewski, R. (2017). Rating Engineering of Real Estate Markets as The Condition of Urban areas Assessment. Land Use Policy 61, 511-525

Ring, A. A and Dasso, J. (1972). Real Estate Principles and Practices. Englewood Cliff, N. J: Prentice Hall Inc.

Scott, I,. (1988). A Knowledge Based Approach to Computer - Assisted Mortagage Valuation of Residential Property. Pontypridd: University of Glamorgan.

Scott, L. M., and Janikas, M. V. (2010). Spatial Statistics in ArcGIS: Software Tools, Methods and Applications. In M. M. Fischer \& A. Getis (Eds.), Handbook of Applied Spatial Analysis (pp. 27-41). Berlin Heidelberg: Springer.

Selamat Jati Yanjah (2017). Personal Communication. Pejabat Residen Daerah Limbang. Timbalan Residen (Pembangunan) Bahagian Limbang, Sarawak.

Shapiro, E., Mackmin, D., and Sams, G. (2009). Modern methods of valuation (10 ed.). London: EG Books.

Shaw, G. and Wheeler, D. (1985). (in Nurul Ainin Mukhatar. 2005). Kesan Peruntukan Efektif Syarikat Harta Tanah Di Bursa Malaysia. Universiti Teknologi Malaysia.

So, H. M., Tse, R. Y. C. and Ganesan, S, . (1997). Estimation the Influence of Transport on House Prices: Evidence from Hong Kong. Journal of Property Valuation and Investment. 15(1): 40 - 47

Tabachnick, B. G. and Fidell, L. S. (1989). Using Multivariate Statistics. Second Edition. New York: Harper Collins.

Watson Jeffry Kaling (2018). Temu bual. Jabatan Penilaian dan Perkhidmatan Harta. Penolong Pegawai Penilaian, Jabatan Penilaian dan Perkhidmatan Harta (JPPH) Cawangan Miri, Sarawak.

Wyatt, P. J. (1997). The Development of Property Information Systems for Real Estate Valuation. International Journal of Geographical Information Systems. 11(5): 435-450

Wyatt , P. J. and Ralphs, M. (2003). GIS in Land and Property Management. Spon Press, Taylor and Francis Group: London. 